\title{
EVALUASI SITUS WEB PARIWISATA \\ WONDERFUL INDONESIA BERDASARKAN MODEL ICTRT \\ (INFORMATION, COMMUNICATION, TRANSACTION, RELATIONSHIP, \\ AND TECHNICAL-MERIT)
}

\author{
I Putu Sudhyana Mecha \\ Universitas Udayana \\ Email: mechaputu@gmail.com \\ Agung Suryawan Wiranatha \\ Universitas Udayana \\ Email: balitruly@yahoo.com \\ I Nyoman Sudiarta \\ Universitas Udayana \\ Email: sudiarta.nyoman@yahoo.co.id
}

\begin{abstract}
Information technology, especially in industrial revolution 4.0 has changed the business practices of every sector, in which tourism is no exception. In Indonesia, the example can be found in case of tourism website Wonderful Indonesia. Given the important role of this website as a DMO (Destination Management Organization) website, then the evaluation was carried out in order to know its progress. This evaluation was based on ICTRT model that it consists of five dimensions, such as information, communication, transaction, relationship, and technical merit. There was 48 indicators on the ICTRT model, which can be divided as follows: information (18 indicators), communication (7 indicators), transaction (5 indicators), relationship (10 indicators), and technical-merit (8 indicators). Result of the Wonderful Indonesia website evaluation were obtained from a questionnaire distributed to 80 respondents, in which the sample came from travel agencies organization namely ASITA Bali. Based on evaluation result via IPA (Importance-Performance Analysis) graph, it showed that the indicators contained in Information, Transaction, and Relationship dimension needs to be considered, given the level of importance was high, but the performance was still low. Therefore, further development is required related to the indicators above, such as accommodation information, local weather information, attraction tickets, virtual tour, and privacy policy.
\end{abstract}

Keywords: ICTRT model, tourism information, DMO website, Wonderful Indonesia 


\section{Pendahuluan}

Teknologi informasi telah berkembang pesat dalam beberapa tahun terakhir ini. Keberadaan internet serta semakin canggihnya perangkat pintar seperti personal computer (PC), laptop, tablet $\mathrm{PC}$, dan smartphone menjadikan seluruh dunia mampu terhubung satu sama lain. Internet of Things, Cloud Computing, Virtual Reality, Big Data, dan Social Media barangkali hanya sedikit dari sekian banyak fenomena teknologi informasi (TI) yang sedang ramai diperbincangkan (Lytras, 2015). Belum lagi jika berbicara tentang media online, seperti misalnya blog, microblog, jejaring sosial, media berbagi, social bookmark, review site, online forum, dan virtual world (Nirmala, 2017). Hal di atas sesuai dengan fenomena yang terjadi saat ini, yaitu revolusi industri 4.0, dimana hampir semua bidang pekerjaan maupun industri mengalami perubahan, tidak terkecuali pariwisata. TI bisa dikatakan berkontribusi besar dalam perubahan yang terjadi dalam praktik bisnis dan strateginya, demikian pula dengan struktur industri yang ada (Buhalis \& Law, 2008).

Penggunaan istilah ekosistem juga dapat digunakan sebagai analogi untuk menggambarkan bagaimana peranan TI dalam pariwisata. Salah satu penerapan ekosistem pariwisata digital dapat dilihat dari bagaimana peranan DMO (Destination Management Organization) dalam rangka menyalurkan informasi mengenai destinasi pariwisata. Ada banyak jenis DMO, seperti national tourism organization, regional tourism organization, dan convention \& visitor bureaus (Pike, 2008). Keberadaan situs web DMO mempunyai fungsi ganda dalam kaitannya dengan promoting maupun managing. Oleh karena itu, sudah seharusnya ada lebih banyak lagi penelitian yang mempelajari tentang situs web DMO tersebut, terutama mengingat perannya sebagai sumber informasi pariwisata.

Indonesia melalui Kementerian Pariwisata dapat dikatakan sebagai DMO, atau lebih tepatnya NTO (national tourism organization) seperti yang sudah diterangkan sebelumnya. Sebagai suatu NTO, Kementerian Pariwisata sudah memiliki situs daring (online) resmi yang menampilkan informasi destinasi wisata di seantero 
Nusantara, yaitu situs web Wonderful Indonesia (dapat dilihat pada tautan berikut: http://www.indonesia.travel/en). Situs web yang yang baik adalah situs yang informatif, komunikatif, handal dalam setiap transaksinya, mampu berhubungan dengan konsumennya atau penggunanya secara interaktif, serta handal secara teknis (Benckendorff dkk., 2014). Jika melihat kondisi saat ini, situs web Wonderful Indonesia masih memiliki banyak kekurangan, terutama jika dilihat pada level kontennya, seperti informasi transportasi dan cuaca (Dewantara, 2015). Mengingat betapa pentingnya peranan situs web dalam penyebaran informasi destinasi wisata nasional, maka diperlukan adanya riset atau penelitian, baik jangka panjang maupun jangka pendek demi perkembangan situs web Wonderful Indonesia.

Berdasarkan penelitian Li \& Wang tahun 2010, maka muncul pemikiran untuk mengevaluasi situs web ini berdasarkan model yang biasa digunakan dalam kasus evaluasi situs web DMO, yaitu model ICTRT (Information, Communication, Transaction, Relationship, Technical-Merit). Ini mengapa evaluasi dilakukan, di samping untuk mengetahui sudah sejauh mana perkembangannya, evaluasi juga dapat dijadikan masukan kepada pihak pengembang situs web tersebut. Mengingat pentingnya evaluasi tersebut, maka pemilihan responden harus didasarkan pada pengalamannya (experience) dalam hal akses informasi pariwisata. Biro perjalanan wisata (travel agent) merupakan salah satu dari sekian banyak praktisi pariwisata yang dipilih sebagai responden penelitian, dimana mereka tergabung dalam keanggotaan ASITA (Association of The Indonesian Tours and Travel Agency). Dengan ditetapkannya praktisi pariwisata sebagai responden penelitian, maka diharapkan hasil evaluasi situs web Wonderful Indonesia objektif dan dapat dijadikan masukan bagi pengembang, utamanya Kementerian Pariwisata sebagai konduktornya. 


\section{Landasan Teori dan Konsep}

\section{Evaluasi Situs Web Pariwisata}

Perkembangan riset maupun studi mengenai teknologi informasi (TI) telah berlangsung dalam dua dekade terakhir. Secara garis besar, era perkembangan TI dapat digolongkan menjadi dua, yaitu era digitalisasi (digitization) dan percepatan (acceleration). Era digitalisasi memang didominasi oleh perkembangan TI yang turut mempengaruhi sektor lain, tidak terkecuali pariwisata. Keberadaan TI dalam pariwisata salah satunya dapat dilihat dari bagaimana peranan TI sebagai suatu alat penggerak pemasaran (marketing-driven tool) pariwisata (Xiang, 2018). Era percepatan diawali dengan kemunculan teknologi, seperti Wi-Fi, search engines, Web 2.0, tablet, smartphone, wearable computers, sensors, internet of things, crowdsourcing, open source, drones, hingga kemunculan machine learning serta artificial intelligence, dan lain-lain. Era ini disebut percepatan karena pesatnya pertumbuhan user-generated content (UGC) di internet, sejalan dengan penyebaran perangkat digital yang tidak hanya diaplikasikan di rumah atau kantor saja, melainkan sudah semakin meluas.

Trend masa depan penelitian mengenai teknologi informasi pariwisata secara umum berfokus pada empat kemungkinan perubahan, yaitu pertumbuhan pariwisata sebagai subject, perubahan di universitas/institusi pendidikan tinggi, perubahan pada pariwisata itu sendiri, dan perubahan pada teknik penelitian. Masih ada banyak lagi topik penelitian yang berkaitan dengan TI dan pariwisata, apalagi jika berbicara tentang fenomena kekinian. Salah satu penelitian yang banyak dilakukan adalah tentang teknologi web (web technology). Poin-poin penting yang biasanya dibahas biasanya berupa konten, design, fitur, dan fungsionalitas. Penelitian mengenai klasifikasi situs web, khususnya situs web pariwisata sudah banyak dilakukan sejauh ini. Salah satunya adalah tentang bagaimana situs web diklasifikasikan menjadi portal sites, travel agency websites, online community sites, public institution sites, dan lain-lain (No \& Kim, 2015). Kemudian, dilihat dari alur 
informasinya, tipe situs web pariwisata dapat dikelompokkan lagi menjadi 2, yaitu travel website dan tourism website. Sedikit berbeda dengan di atas, ada lagi sumber informasi pariwisata online yang dibagi menjadi 4 macam, yakni social websites, personal websites, marketing (corporate) websites, dan editorial websites. Namun, penelitian-penelitian sebelumnya lebih banyak menyarankan untuk membagi situs web pariwisata menjadi 4 macam kategori, yaitu personal blog, public website, company website, dan website for social media.

Saat ini hampir sebagian besar orang menggunakan situs web pariwisata yang mampu menyediakan informasi mengenai daerah tujuan wisata potensialnya. Internet memungkinkan wisatawan untuk mengakses informasi yang reliabel dan akurat, sekaligus juga memangkas waktu, biaya, dan ketidaknyamanan yang dulunya dilakukan dengan cara konvensional (Lim \& Yoo, 2012). Bisa dikatakan bahwa keberadaan situs web pariwisata secara bertahap telah menggantikan peran travel guide yang sifatnya paper-based, di samping juga turut meningkatkan jumlah situs web pariwisata itu sendiri. Inilah yang perlu diperhatikan agar perkembangan situs web pariwisata tidak hanya unggul dari sisi kuantitas saja, tetapi juga kualitasnya. Evaluasi situs web merupakan suatu tindakan yang dilakukan dalam rangka menentukan requirement yang benar dan komprehensif, dimana hal ini bertujuan untuk memastikan suatu situs web mampu menyediakan konten yang bermanfaat guna memenuhi ekspektasi pengguna (user) serta tepat guna (Yannacopoulos dkk., 2014).

\section{Model ICTRT (Information, Communication, Transaction, Relationship, and Technical-merit)}

Dalam kaitannya dengan evaluasi situs web pariwisata, model ICTRT biasa digunakan sebagai acuan. Model ini terdiri atas 5 macam dimensi, dimana sesuai dengan kepanjangannya, yaitu dimensi Information, Communication, Transaction, Relationship, dan Technical-Merit. Keseluruhan dimensi ini terdiri dari 48 indikator yang dapat dibagi sebagai berikut: dimensi informasi sebanyak 18 indikator, 
dimensi komunikasi sebanyak 7 indikator, dimensi transaksi sebanyak 5 indikator, dimensi hubungan sebanyak 10 indikator, dan dimensi teknis sebanyak 8 indikator.

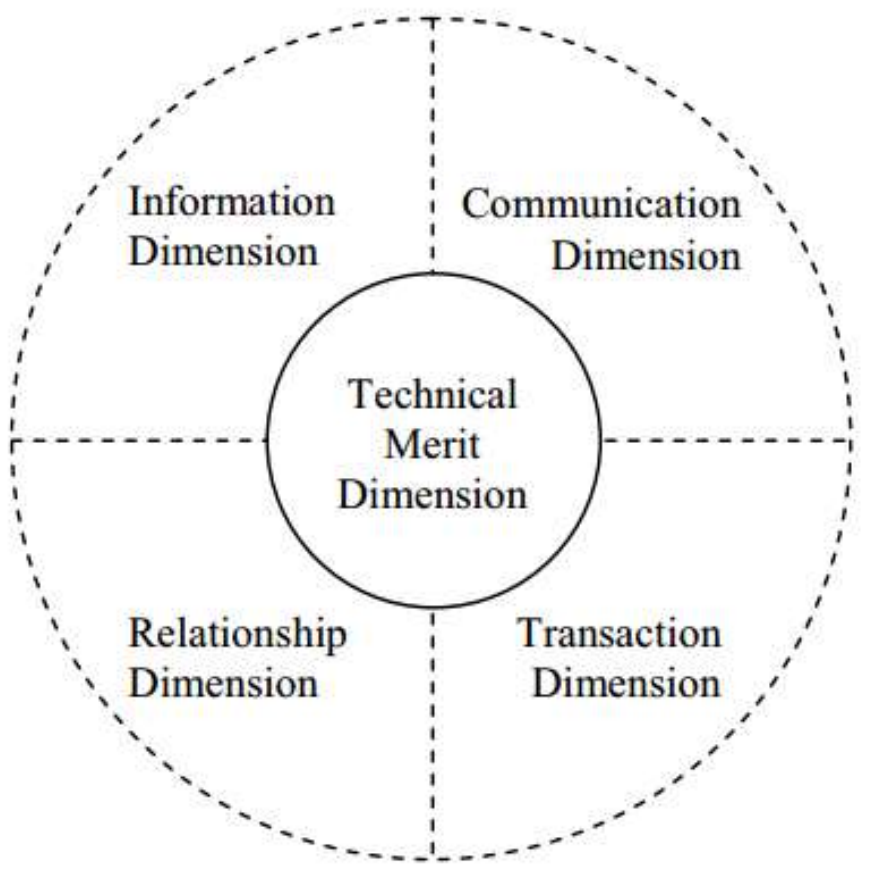

Gambar 1. Model ICTRT (Adaptasi dari Li \& Wang, 2010)

Tabel 1. Indikator dari masing-masing dimensi pada model ICTRT

\begin{tabular}{|c|c|c|}
\hline \multirow[t]{14}{*}{$\begin{array}{c}\text { Dimensi Informasi } \\
\text { (Information; total = 18) }\end{array}$} & 1. & $\begin{array}{l}\text { Informasi daya tarik wisata } \\
\text { (Attraction information) }\end{array}$ \\
\hline & 2. & $\begin{array}{l}\text { Informasi aktivitas wisata } \\
\text { (Activities information) }\end{array}$ \\
\hline & 3. & $\begin{array}{l}\text { Peta dan petunjuk arah } \\
\text { (Maps and directions) }\end{array}$ \\
\hline & 4. & $\begin{array}{l}\text { Informasi latar belakang destinasi } \\
\text { (Destination background information) }\end{array}$ \\
\hline & 5. & $\begin{array}{l}\text { Produk tema } \\
\text { (Themed products) }\end{array}$ \\
\hline & 6. & $\begin{array}{l}\text { Informasi transportasi } \\
\text { (Transportation information) }\end{array}$ \\
\hline & 7. & $\begin{array}{l}\text { Kalendar event } \\
(\text { Events calendar })\end{array}$ \\
\hline & 8. & $\begin{array}{l}\text { Informasi restoran } \\
\text { (Restaurant information) }\end{array}$ \\
\hline & 9. & $\begin{array}{l}\text { Panduan wisata/brosur } \\
\text { (Travel guides/brochures) }\end{array}$ \\
\hline & 10. & $\begin{array}{l}\text { Agen wisata } \\
\text { (Travel agents) }\end{array}$ \\
\hline & 11. & $\begin{array}{l}\text { Informasi akomodasi } \\
\text { (Accommodation information) }\end{array}$ \\
\hline & 12. & $\begin{array}{l}\text { Paket perjalanan wisata } \\
\text { (Travel packages) }\end{array}$ \\
\hline & 13. & $\begin{array}{l}\text { Informasi hiburan } \\
\text { (Entertainment information) }\end{array}$ \\
\hline & 14. & $\begin{array}{l}\text { Informasi cuaca local } \\
\text { (Local weather information) }\end{array}$ \\
\hline
\end{tabular}


Evaluasi Situs Web Pariwisata Wonderful Indonesia berdasarkan Model ICTRT

\begin{tabular}{|c|c|c|}
\hline & 15. & $\begin{array}{l}\text { Informasi belanja } \\
\text { (Shopping information) }\end{array}$ \\
\hline & 16. & $\begin{array}{l}\text { Tips perjalanan wisata } \\
\text { (Travel tips) }\end{array}$ \\
\hline & 17. & $\begin{array}{l}\text { Perencana perjalanan wisata/liburan } \\
\text { (Trip/vacation planner) }\end{array}$ \\
\hline & 18. & $\begin{array}{l}\text { Terhubung dengan laman daerah/kota/area } \\
\text { (Linked to regional/city/area pages) }\end{array}$ \\
\hline \multirow[t]{7}{*}{$\begin{array}{c}\text { Dimensi Komunikasi } \\
(\text { Communication; total }=7)\end{array}$} & 19. & $\begin{array}{l}\text { Fungsi pencarian } \\
\text { (Search function) }\end{array}$ \\
\hline & 20. & $\begin{array}{l}\text { Alat komunikasi interaktif } \\
\text { (Interactive communication tools) }\end{array}$ \\
\hline & 21. & $\begin{array}{l}\text { Forum daring } \\
(\text { Online forum })\end{array}$ \\
\hline & 22. & $\begin{array}{l}\text { Kolom komentar } \\
(\text { Comment box })\end{array}$ \\
\hline & 23. & $\begin{array}{l}\text { Survei daring } \\
(\text { Online survey })\end{array}$ \\
\hline & 24. & $\begin{array}{l}\text { Daftar pertanyaan yang sering diajukan } \\
\text { (Frequently asked questions) }\end{array}$ \\
\hline & 25. & $\begin{array}{l}\text { Kumpulan berita berkala melalui surel } \\
\text { (Email newsletter) }\end{array}$ \\
\hline \multirow[t]{5}{*}{$\begin{array}{c}\text { Dimensi Transaksi } \\
(\text { Transaction; total }=5)\end{array}$} & 26. & $\begin{array}{l}\text { Pemesanan daring } \\
(\text { Online reservation })\end{array}$ \\
\hline & 27. & $\begin{array}{l}\text { Pemesanan yang aman } \\
\text { (Secure reservation) }\end{array}$ \\
\hline & 28. & $\begin{array}{l}\text { Tiket masuk daya tarik wisata } \\
\text { (Attraction tickets) }\end{array}$ \\
\hline & 29. & $\begin{array}{l}\text { Tiket event } \\
\text { (Events tickets) }\end{array}$ \\
\hline & 30. & $\begin{array}{l}\text { Kereta belanja } \\
\text { (Shopping carts) }\end{array}$ \\
\hline \multirow[t]{10}{*}{$\begin{array}{c}\text { Dimensi Hubungan } \\
\text { (Relationship; total }=10)\end{array}$} & 31. & $\begin{array}{l}\text { Personalisasi } \\
(\text { Personalization })\end{array}$ \\
\hline & 32. & $\begin{array}{l}\text { Penanganan keluhan } \\
\text { (Complains handling) }\end{array}$ \\
\hline & 33. & $\begin{array}{l}\text { Kesepakatan terbaik } \\
\text { (Best deals) }\end{array}$ \\
\hline & 34. & $\begin{array}{l}\text { Tur virtual } \\
\text { (Virtual tours) }\end{array}$ \\
\hline & 35. & $\begin{array}{l}\text { Peluang penjualan dari pihak lain } \\
\text { (Cross-selling opportunities) }\end{array}$ \\
\hline & 36. & $\begin{array}{l}\text { Kebijakan terkait privasi } \\
\text { (Privacy policy) }\end{array}$ \\
\hline & 37. & $\begin{array}{l}\text { Penawaran spesial } \\
\text { (Special offers) }\end{array}$ \\
\hline & 38. & $\begin{array}{l}\text { Sertifikasi segel web } \\
(\text { Web seal certification })\end{array}$ \\
\hline & 39. & $\begin{array}{l}\text { Program untuk pelanggan yang loyal } \\
\text { (Customer loyalty programmes) }\end{array}$ \\
\hline & 40. & $\begin{array}{l}\text { Program insentif } \\
\text { (Incentive programmes) }\end{array}$ \\
\hline \multirow[t]{8}{*}{$\begin{array}{c}\text { Dimensi Teknis } \\
(\text { Technical }- \text { merit } ; \text { total }=8)\end{array}$} & 41. & $\begin{array}{l}\text { Pengenalan mesin pencari } \\
\text { (Search engine recognition) }\end{array}$ \\
\hline & 42. & $\begin{array}{l}\text { Desain halaman web } \\
\text { (Webpage design) }\end{array}$ \\
\hline & 43. & $\begin{array}{l}\text { Tautan } \\
\text { (Link check) }\end{array}$ \\
\hline & 44. & $\begin{array}{l}\text { Waktu } \\
\text { (Load time) }\end{array}$ \\
\hline & 45. & $\begin{array}{l}\text { Navigasi } \\
\text { (Navigation) }\end{array}$ \\
\hline & 46. & $\begin{array}{l}\text { Tampilan visual } \\
\text { (Visual appearance) }\end{array}$ \\
\hline & 47. & $\begin{array}{l}\text { Peta situs } \\
\text { (Sitemap) }\end{array}$ \\
\hline & 48. & $\begin{array}{l}\text { Layanan bahasa yang beragam } \\
\text { (Multiple language) }\end{array}$ \\
\hline
\end{tabular}

(Sumber: Li \& Wang, 2010) 
Gambaran singkat mengenai masing-masing dimensi tersebut ketika hendak dikaitkan dengan situs web Wonderful Indonesia dapat dijelaskan sebagai berikut. Dimensi informasi berkaitan dengan bagaimana suatu informasi dapat selalu berjalan secara real-time dan selalu up-to-date. Dimensi komunikasi berkaitan dengan bagaimana membangun komunikasi yang efektif dan berkelanjutan dengan pengguna, dalam kasus ini bisa wisatawan atau pengguna situs web. Dimensi transaksi berkaitan dengan bagaimana kemudahan akses transaksi serta kehandalannya. Dimensi hubungan terkait dengan bagaimana membangun suatu hubungan yang berkelanjutan dengan pengguna. Terakhir, dimensi teknis yaitu bagaimana situs web mampu menyesuaikan dengan keberadaan fitur-fitur terbaru, utamanya fitur yang berkaitan erat dengan konektivitas internet.

\section{Metode Penelitian}

Penelitian mengenai evaluasi situs web Wonderful Indonesia ini dihimpun berdasarkan data yang berasal dari praktisi pariwisata. Pemilihan sampel atau sampling dilakukan atas dasar bahwa situs web ini merupakan situs web milik pemerintah, dalam hal ini Kementerian Pariwisata Republik Indonesia. Target sampel yang hendak dikumpulkan adalah praktisi pariwisata yang merupakan anggota ASITA Bali, dimana sampel tersebut merupakan bagian dari praktisi pariwisata se-Bali. Jumlah populasinya adalah sebanyak total 408 organisasi. Pengambilan sampel berfokus pada hasil kuesioner yang disebar pada total sampel sebanyak 80 responden.

Mengingat bahwa pihak-pihak pendukung kegiatan kepariwisataan adalah akademisi, pemerintah, serta praktisi, maka dengan adanya cross check berdasarkan survei dari praktisi pariwisata ini diharapkan agar hasil evaluasinya objektif dan sesuai dengan fakta yang terjadi di lapangan. Hasil evaluasi (result) seringkali bermasalah ketika indikator dari penelitian tidak mampu diterjemahkan menjadi tindakan nyata (action). Penelitian empiris yang ada telah membuktikan bahwa dua atribut ini, yaitu tingkat kepentingan (importance) dan tingkat kinerja (performance) 
mampu menjawab ekspektasi konsumen atau pengguna (Martilla \& James, 1977). Dengan demikian, dapat dikatakan bahwa kedua atribut sangat berguna untuk melalukan evaluasi terhadap elemen atau indikator dari suatu kegiatan pemasaran, termasuk di dalamnya mempromosikan ataupun menyebarkan informasi mengenai pariwisata. Itulah mengapa analisis tingkat kepentingan-kinerja (importanceperformance analysis) dilakukan, sebagai tahap lanjut dari perumusan indikator yang telah dilakukan sebelumnya.

IPA biasanya disajikan dalam bentuk grid dua dimensi, yang terdiri atas empat buah buah kuadran (dari rentang I-IV). Jika dihubungkan dengan indikator yang terdapat dalam model ICTRT, maka secara garis besar grid IPA dapat dinyatakan sebagai berikut.

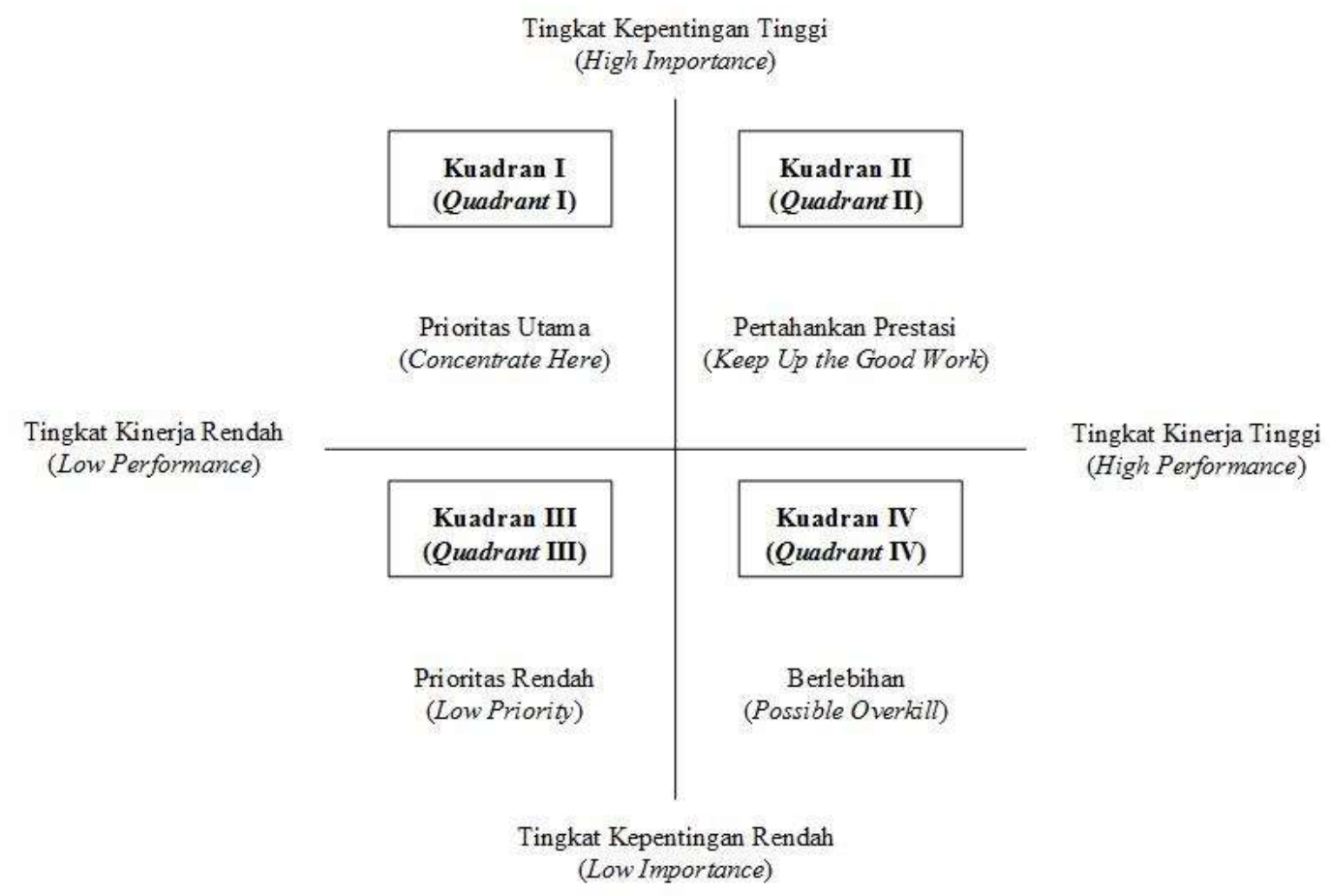

(Sumber: Martilla \& James, 1977)

- $\quad$ Kuadran I : Perhatikan disini (Concentrate Here)

Tingkat kepentingan terhadap indikator menurut pengguna cukup tinggi, namun tingkat kinerja situs web Wonderful Indonesia masih rendah (belum bias mengimbangi). 
- $\quad$ Kuadran II : Pertahankan (Keep Up the Good Work) Tingkat kepentingan terhadap indikator menurut pengguna cukup tinggi, dan tingkat kinerja situs web Wonderful Indonesia mampu mengimbanginya (sama sama cukup tinggi).

- $\quad$ Kuadran III : Prioritas rendah (Low Priority)

Tingkat kepentingan terhadap indikator menurut pengguna cukup rendah, serta dibarengi dengan tingkat kinerja situs web Wonderful Indonesia yang memang rendah pula.

- $\quad$ Kuadran IV : Mungkin berlebihan (Possible Overkill)

Tingkat kepentingan terhadap indikator menurut pengguna cukup rendah, namun tingkat kinerja situs web Wonderful Indonesia terlampau tinggi (berlebihan).

Rentang nilai dari setiap kuadran dirumuskan sesuai dengan total rata-rata yang diperoleh berdasarkan skala Likert 1-5. Satu indikator mewakili satu buah titik yang ditempatkan sesuai dengan kuadrannya, sehingga hasil evaluasi berpedoman pada jumlah total titik-titik tersebut. Kemudian, dari sini dapat diambil simpulan mengenai indikator mana saja yang perlu untuk ditingkatkan ataupun diperhatikan, baik dari sisi importance maupun performance-nya. Wawancara terhadap beberapa informan ahli juga ditambahkan sebagai penunjang hasil evaluasi tersebut.

\section{Hasil Penelitian}

Hasil evaluasi digambarkan dengan grafik IPA (Importance-Performance Analysis). Grafik yang berupa scatter plot ini terdiri atas 48 titik, dimana setiap titik merupakan representasi dari indikator penelitian. Gambaran mengenai grafik hasil evaluasi dapat dilihat di bawah ini. 


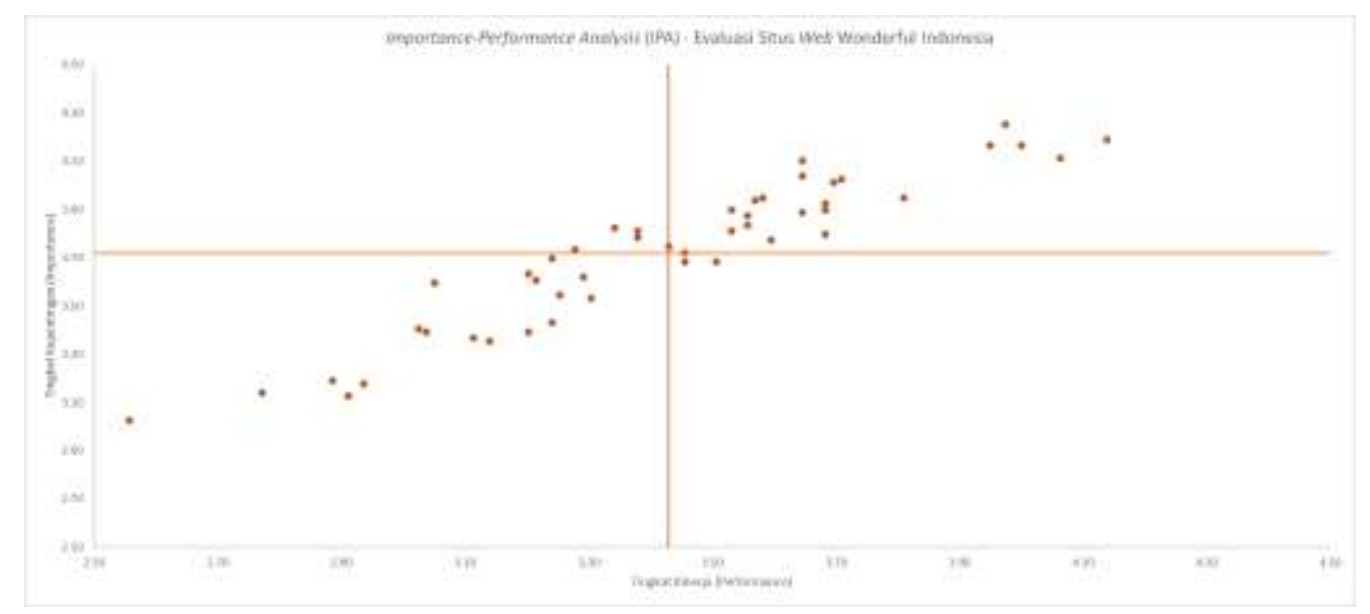

Gambar 2. Grafik IPA (Importance-Performance Analysis)

\section{Kuadran I (Concentrate Here)}

Indikator yang termasuk dalam kuadran I adalah:

\section{Dimensi informasi (Information)}

11. Informasi akomodasi (Accommodation information)

14. Informasi cuaca lokal (Local weather information)

\section{Dimensi transaksi (Transaction)}

28. Tiket masuk daya tarik wisata (Attraction tickets)

\section{Dimensi hubungan (Relationship)}

34. Tur virtual (Virtual tour)

36. Kebijakan terkait privasi (Privacy policy) 


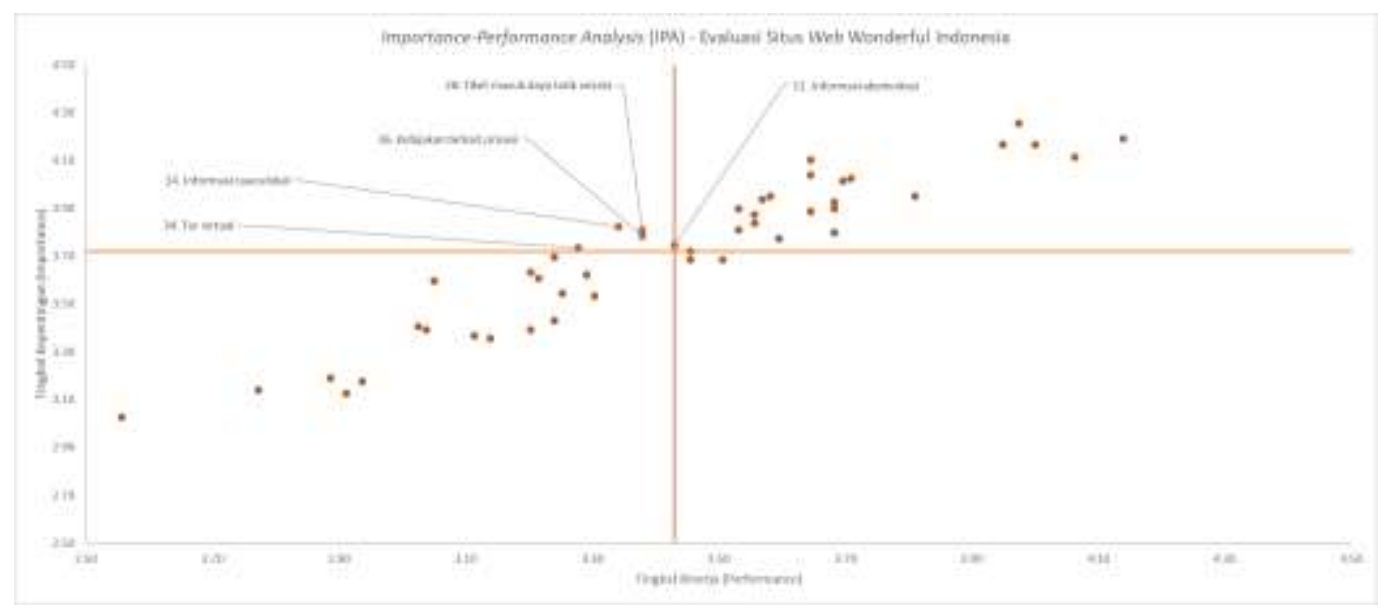

Gambar 3. Kuadran I (Concentrate Here)

\section{Kuadran II (Keep Up The Good Work)}

Indikator yang termasuk dalam kuadran II adalah:

\section{Dimensi informasi (Information)}

1. Informasi daya tarik wisata (Attraction information)

2. Informasi aktivitas wisata (Activities information)

3. Peta dan petunjuk arah (Maps and directions)

4. Informasi latar belakang destinasi (Destination background information)

5. Produk tema (Themed products)

6. Informasi transportasi (Transportation information)

7. Kalendar event (Events calendar)

8. Informasi restoran (Restaurant information)

9. Panduan wisata/brosur (Travel guides/brochures)

10. Agen wisata (Travel agents)

12. Paket perjalanan wisata (Travel packages)

13. Informasi hiburan (Entertainment information)

16. Tips perjalanan wisata (Travel tips)

17. Perencana perjalanan wisata/liburan (Trip/vacation planner) 


\section{Dimensi komunikasi (Communication)}

19. Fungsi pencarian (Search function)

\section{Dimensi hubungan (Relationship)}

37. Penawaran spesial (Special offers)

\section{Dimensi teknis (Technical-merit)}

42. Desain halaman web (Webpage design)

43. Tautan (Link check)

44. Waktu (Load time)

46. Tampilan visual (Visual appearance)

47. Peta situs (Sitemap)

48. Layanan bahasa yang beragam (Multiple language)

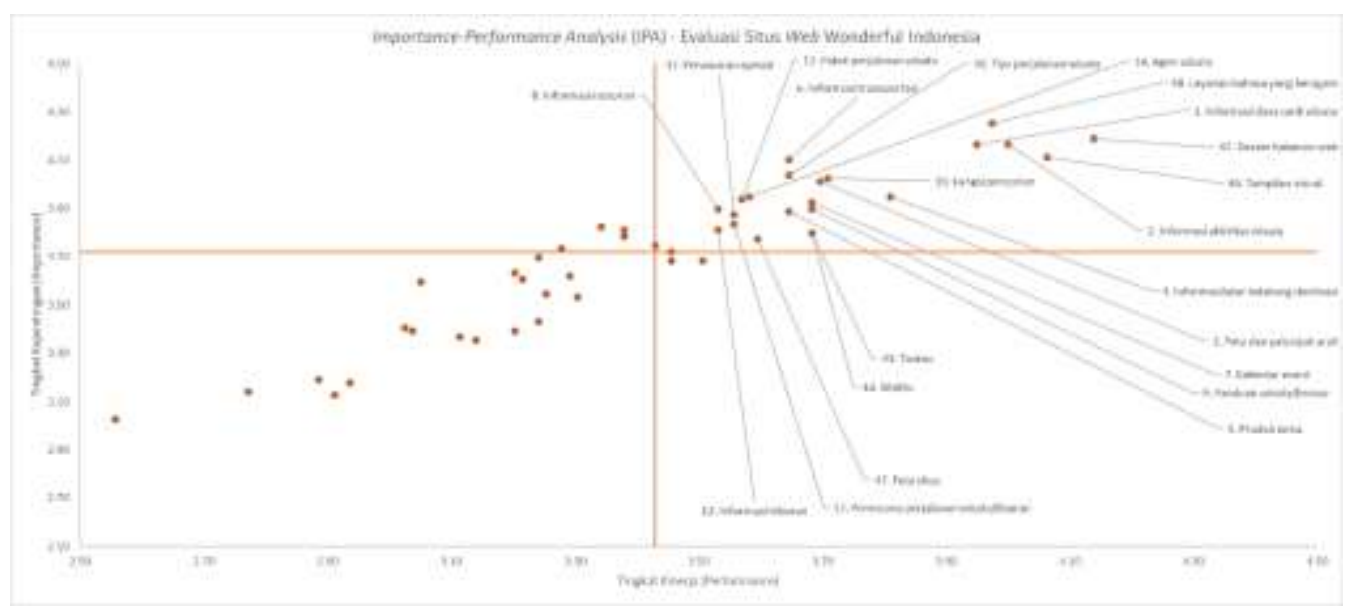

Gambar 4. Kuadran II (Keep Up The Good Work)

\section{Kuadran III (Low Priority)}

Indikator yang termasuk dalam kuadran III adalah:

\section{Dimensi informasi (Information)}

15. Informasi belanja (Shopping information)

\section{Dimensi komunikasi (Communication)}

20. Alat komunikasi interaktif (Interactive communication tools)

21. Forum daring (Online forum)

22. Kolom komentar (Comment box) 
23. Survei daring (Online survey)

24. Daftar pertanyaan yang sering diajukan (Frequently asked questions)

25. Kumpulan berita berkala melalui surel (Email newsletter)

\section{Dimensi transaksi (Transaction)}

26. Pemesanan daring (Online reservation)

27. Pemesanan yang aman (Secure reservation)

29. Tiket event (Events tickets)

30. Kereta belanja (Shopping carts)

\section{Dimensi hubungan (Relationship)}

31. Personalisasi (Personalization)

32. Penanganan keluhan (Complaints handling)

38. Sertifikasi segel web (Web seal certification)

39. Program untuk pelanggan yang loyal (Customer loyalty programmes)

40. Program insentif (Incentive programmes)

\section{Dimensi teknis (Technical-merit)}

41. Pengenalan mesin pencari (search engine recognition)

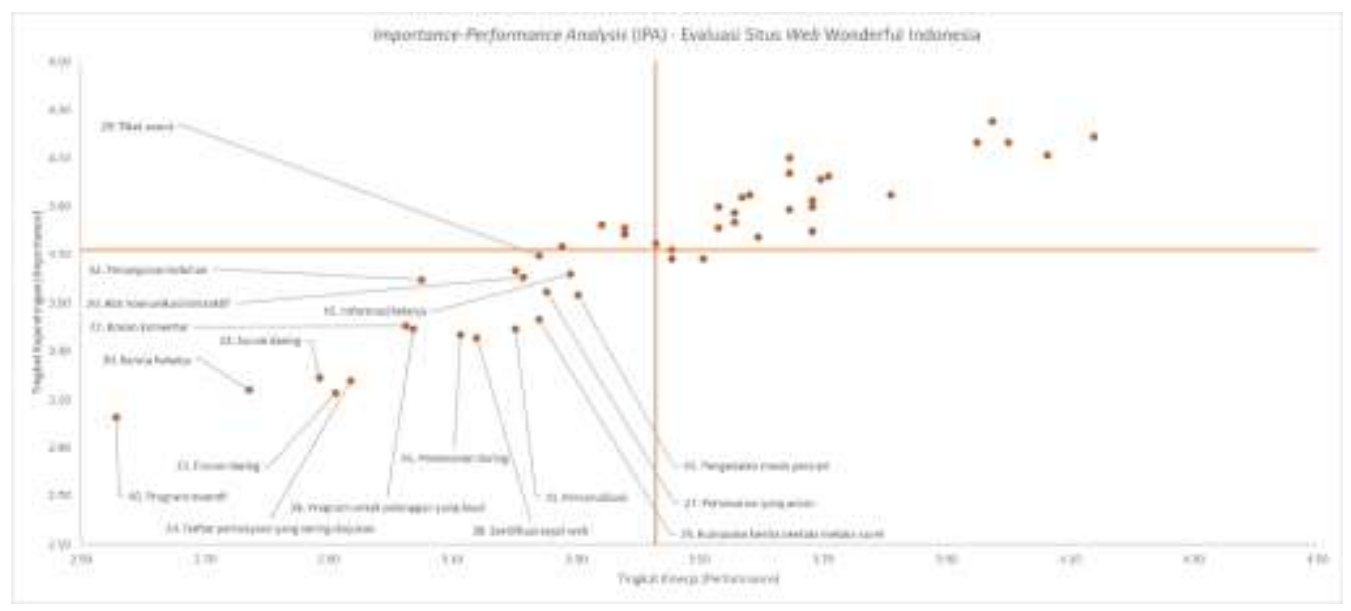

Gambar 5. Kuadran III (Low Priority) 


\section{Kuadran IV (Possible Overkill)}

Indikator yang termasuk dalam kuadran IV adalah:

\section{Dimensi informasi (Information)}

18. Tautan menuju laman daerah/kota/area

(Linked to regional/city/area pages)

\section{Dimensi hubungan (Relationship)}

35. Peluang penjualan dari pihak lain (Cross-selling opportunities)

Dimensi teknis (Technical-merit)

45. Navigasi (Navigation)

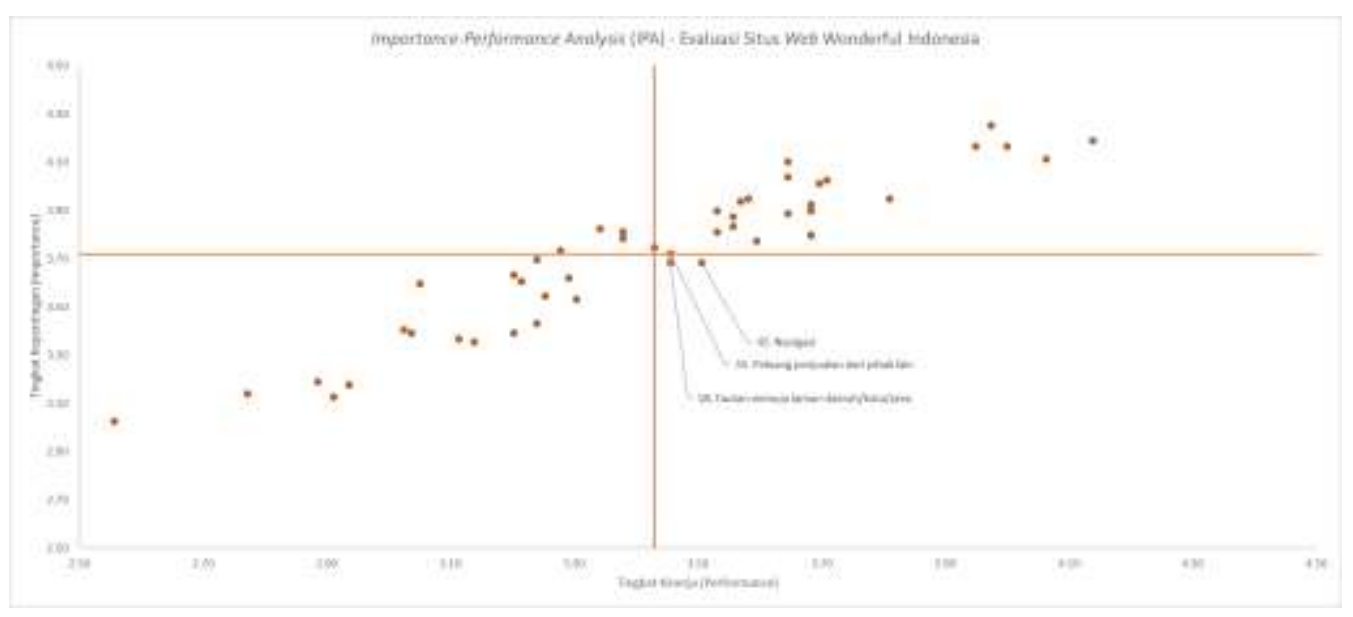

Gambar 6. Kuadran IV (Possible Overkill)

\section{Pembahasan}

Evaluasi situs web Wonderful Indonesia dianalisis dengan menggunakan IPA (Importance-Performance Analysis). Berdasarkan grafik IPA, terlihat dengan jelas bahwa masih banyak indikator yang perlu dikembangkan dalam rangka peningkatan tingkat kepentingan maupun tingkat kinerja dari situs web ini. Secara khusus, terlihat bahwa ada 3 dimensi yang indikatornya terdapat di dalam kuadran I, yaitu dimensi informasi (Information), transaksi (Transaction), dan hubungan (Relationship). Kuadran I, yaitu Concentrate Here merupakan kuadran yang 
seharusnya mendapat perhatian lebih. Hal ini karena semua indikator di dalam kuadran ini bisa dikatakan telah diadaptasi oleh situs web Wonderful Indonesia. Kinerjanya masih dianggap kurang maksimal, padahal penting sekali kegunaannya.

Dengan melihat hasil yang terdapat pada kuadran I, maka diperlukan adanya perhatian terhadap indikator dimensi informasi (Information), yaitu informasi cuaca lokal (local weather information) dan informasi akomodasi (accommodation information). Untuk dimensi transaksi (transaction), yang perlu diperhatikan adalah tiket masuk daya tarik wisata (attraction tickets). Kemudian, untuk dimensi hubungan (relationship), perlu diperhatikan mengenai indikator tur virtual (virtual tour) dan kebijakan terkait privasi (privacy policy).

Berdasarkan penjelasan yang sudah dijabarkan di atas, maka rencana pengembangan situs web Wonderful Indonesia bisa dikatakan berpedoman pada hasil evaluasi, dimana berdasarkan grafik important-performance analysis yang terdapat dalam kuadran I (Concentrate Here). Selain itu, wawancara terhadap informan yang berasal dari stakeholder terkait, yaitu pemerintah, praktisi pariwisata, serta akademisi turut menunjang hasil evaluasi tersebut. Dengan ditemukannya 5 indikator pada kuadran I, maka sudah seyogianya dimensi informasi, transaksi, dan hubungan dikembangkan lebih lanjut, sekalipun sekarang situs web ini masih belum berkembang menuju jalur komersial. Jika berbicara dari dimensi transaksi, maka sudah jelas bahwa terdapat pernyataan atau disclaimer yang menunjukkan situs web ini bukan bersifat komersial. Namun, pengembangan ke depannya bisa jadi tetap bersinggungan dengan dimensi transaksi, walaupun barangkali dalam penerapannya tetap difokuskan pada dimensi informasi, hubungan ataupun dimensi-dimensi lainnya. Untuk itu, pengembangan situs web Wonderful Indonesia masih memerlukan masukan serta implementasi nyata dalam rangka mewujudkan pariwisata nasional yang sesuai dengan slogan wonderful tersebut. 


\section{Simpulan dan Saran}

Simpulan yang bisa diambil dari penelitian ini adalah bahwa indikatorindikator dimensi informasi, transaksi, dan hubungan yang terdapat dalam model ICTRT perlu diperhatikan, utamanya dalam kaitannya dengan pengembangan selanjutnya. Indikator yang dimaksud yaitu: informasi cuaca lokal (local weather information), informasi akomodasi (accomodation information), tiket masuk daya tarik wisata (attraction tickets), tur virtual (virtual tour), dan kebijakan terkait privasi (privacy policy), sesuai dengan yang ditunjukkan pada grafik IPA hasil evaluasi (kuadran I - Concentrate Here).

Sedangkan, saran yang diperlukan adalah adanya implementasi nyata agar fitur-fitur penting yang seyogianya perlu diperhatikan bisa dibangun sesuai dengan kebutuhan pengguna, di samping perlu adanya penyesuaian terhadap kebutuhan informasi pengguna, khususnya wisatawan sebagai pengguna utamanya.

\section{Daftar Pustaka}

Benckendorff, P. J., Sheldon, P. J. \& Fesenmaier, D. R., 2014. Tourism Information Technology, 2nd Edition. Boston, MA: CABI.

Buhalis, D. \& Law, R., 2008. Progress in information technology and tourism management: 20 years on and 10 years after the internet: The state of eTourism research. Tourism Management, Volume 29, pp. 609-623.

Dewantara, M. H., 2015. Analisis dan Pengembangan Situs Resmi Pariwisata Indonesia dan Sistem Informasi Pendukungnya. Jurnal Master Pariwisata,1(2), pp. 9-24.

Lim, Y. S. \& Yoo, E. E., 2012. TripAdvisor.com vs. NYCGO.com: Evaluation of Functional Components of Generalist and Specialist Tourism Websites. Helsingborg, Sweden, Springer, pp. 120-131.

Li, X. \& Wang, Y., 2010. Evaluating the Effectiveness of Destination Marketing Organisations Websites: Evidence from China. International Journal of Tourism Research, Volume 12, pp. 536-549.

Lytras, M. D., 2015. Enabling Technologies and Business Infrastructures for Next Generation Social Media: Big Data, Cloud Computing, Internet of Things and Virtual Reality. Journal of Universal Computer Science, 21(11), pp. 1379-1384. 
Martilla, J. A. \& James, J. C., 1977. Importance-Performance Analysis. Journal of Marketing, 41(1), pp. 77-79.

Nirmala, B. P. W., 2017. Persepsi Pengelola Hotel Bintang 1-5 terhadap Fungsi dan Fitur Media Pemasaran Online di Kecamatan Kuta, Provinsi Bali. Jurnal Master Pariwisata, 3(2), pp. 356-371.

No, E. \& Kim, J. K., 2015. Comparing the attributes of online tourism information sources. Computers in Human Behavior, Volume 50, pp. 564-575.

Pike, S., 2008. Destination Marketing: An Integrated Marketing Communication Approach. Oxford, UK: Elsevier Inc.

Xiang, Z., 2018. From digitization to the age of acceleration: On information technology and tourism. Tourism Management Perspectives, Volume 25, pp. 147150.

Yannacopoulos, D., Manolitzas, P., Matsatsinis, N. \& Grigoroudis, E., 2014. Evaluating Websites and Web Services: Interdisciplinary Perspectives on User Satisfaction. United States of America: IGI Global.

\section{Profil Penulis}

I Putu Sudhyana Mecha adalah alumnus Program Studi Magister Pariwisata Universitas Udayana tahun 2018 dan Sarjana Jurusan Teknik Informatika Institut Teknologi Sepuluh Nopember (ITS) Surabaya tahun 2014. Minat penelitian Mecha adalah tentang web $\mathcal{E}$ mobile development dan e-tourism.

Agung Suryawan Wiranatha adalah Dosen Magister Pariwisata Universitas Udayana, sekaligus sebagai Kepala Pusat Penelitian Kebudayaan dan Pariwisata Universitas Udayana. Minat penelitian Agung Suryawan adalah ecotourism dan sustainable tourism.

I Nyoman Sudiarta adalah Dosen Magister Pariwisata Universitas Udayana, dan kini menjabat sebagai Wakil Dekan II Fakultas Pariwisata Universitas Udayana. Minat penelitian Sudiarta adalah tourism marketing. 